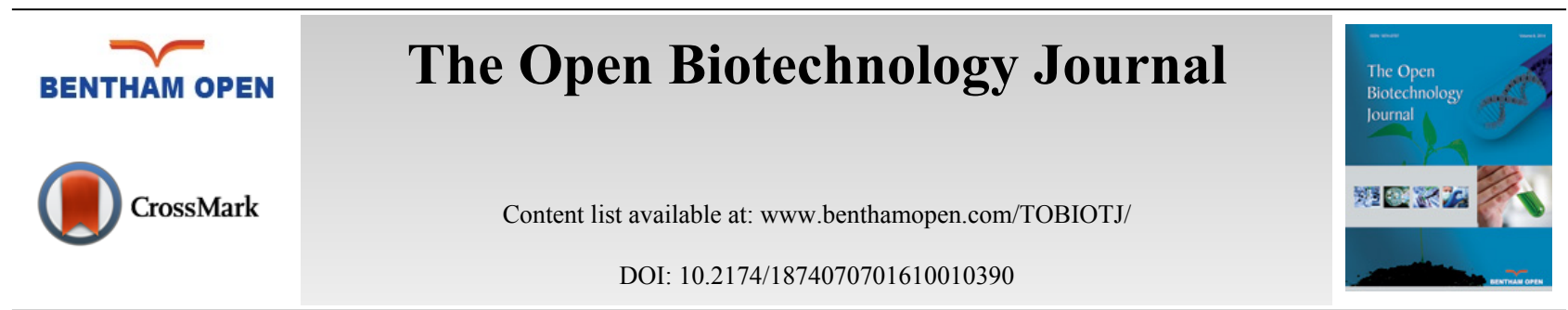

RETRACTION

\title{
Retraction Notice: Study of Intelligent Agricultural Cultivation Management Plan Model Based on Geographic Information System
}

Chuang Lu, Bo Wang ${ }^{*}$, Xiu-Yuan Peng, Xiao-Lei Hou, Bing Bai and Chun-Meng Wang

Liaoning Academy of Agricultural Sciences, Shenyang, Liaoning, China

\section{RETRACTION}

The Publisher and Editor have retracted this article [1] in accordance with good ethical practices. After thorough investigations we believe that the peer review process was compromised. The article was published online on 14-09-2015.

\section{REFERENCE}

[1] Lu C, Wang B, Peng X-Y, Hou X-L, Bai B, Wang C-M. Study of intelligent agricultural cultivation management plan model based on geographic information system. Open Biotech J 2015; 9: 150-6.

(C) Lu et al.; Licensee Bentham Open.

This is an open access article licensed under the terms of the Creative Commons Attribution-Non-Commercial 4.0 International Public License (CC BY-NC 4.0) (https://creativecommons.org/licenses/by-nc/4.0/legalcode), which permits unrestricted, non-commercial use, distribution and reproduction in any medium, provided the work is properly cited.

\footnotetext{
* Address correspondence to this author at the Liaoning Academy of Agricultural Sciences, Shenyang, Liaoning, China; E-mail: aidilunzi@hotmail.com.
} 